\title{
TELETANDEM MEDIATION ON FACEBOOK
}

\section{Mediação de Teletandem por meio do Facebook}

\author{
Daniela Nogueira de Moraes GARCIA \\ Micheli Gomes de SOUZA²
}

\begin{abstract}
Teletandem is a telecollaborative learning context, which involves the process of pairing up language learners of different institutions around the world. Since 2006, institutional teletandem practice has involved the offer of pedagogical mediation to support learners' development. The mediation aims to provide teletandem participants a context for sharing experience and reflecting on their language and intercultural learning process. This article aims at describing the mediation session procedures and the findings of a study carried out during teletandem interactions between students from Brazil and from the United States. A private Facebook group was used to support the contact between the mediator and students of the Brazilian university. In this work, we present the review of the concept of mediation in teletandem and present the results of an interpretivist qualitative analysis that show that the role of the mediator is focused on providing encouragement and guidelines based on teletandem theory and principles. We also point out the study limits and propose some possibilities for future research that might focus on mediation sessions through virtual platforms or social networks.
\end{abstract}

Keywords | Institutional teletandem. Mediation sessions through Facebook. Role of the mediator.
Resumo | Teletandem é um contexto telecolaborativo de aprendizagem que envolve o estabelecimento de parcerias entreaprendizes de línguas ao redor do mundo. Desde 2006, a prática institucional de teletandem tem envolvido a oferta de mediação pedagógica para dar suporte ao desenvolvimento dos aprendizes. A mediação tem como objetivo prover aos participantes de teletandem um contexto para o compartilhamento de experiências e reflexões sobre seu processo de aprendizagem linguística e intercultural. Este artigo tem como objetivo descrever os procedimentos de mediação e os resultados de um estudo realizado a partir de interações entre aprendizes do Brasil e dos Estados Unidos. Um grupo fechado de Facebook foi utilizado para apoiar o contato entre mediadora e aprendizes de uma universidade brasileira. Neste trabalho, fazemos uma revisão do conceito de mediação no teletandem e apresentamos os resultados de uma análise qualitativa interpretativista que revelam que o papel do mediador é focado na promoção de encorajamento e direcionamentos baseados nas teorias e princípios básicos do teletandem. Apresentamos também os limites do nosso estudo e propomos algumas possibilidades para pesquisas futuras com foco nas sessões de mediação por meio de plataformas virtuais e redes sociais.

Palavras-chave | Teletandem institucional. Sessões de mediação via Facebook. Papel do mediador.

\footnotetext{
1 Garcia. UNESP. E-mail: dany7garcia@gmail.com. ORCID ID: https://orcid.org/0000-0003-2813-7538 
- | Teletandem mediation on Facebook

\section{Introduction}

Web-based technologies have been providing proficuous contexts for pedagogical instruction in foreign languages. They have also fostered transcultural communication by highlighting possibilities and promoting educational partnerships. According to Vassallo $\&$ Telles (2009), the association of image, voice and written resources has reinforced these perspectives of transcultural communication. The authors believe that the learners can now have direct access to daily communication in different languages and with people from all around the world, by using the internet and synchronous communication technologies (VASSALLO; TELLES, 2009).

Schenker (2012) mentions that globalization requires diversified competencies and an education system that focuses on teaching the students the necessary abilities for the new needs and changes. The borders limiting communication between people located in distant geographical areas are shifting and disappearing as technologies and international relations emerge (WELSCH, 1999).

Telecollaboration is of particular interest with respect to Computer Mediated Communication and Computer Assisted Language Learning. According to O'Dowd (2015, p. 63), "one of the essential CMC activities in foreign language education is undoubtedly telecollaboration". Belz (2003) posits that it involves global computer networks to foreign (and second) language learning and teaching in institutionalized settings for internationally-dispersed learners that use it in parallel to language classes in order to support social interaction, and intercultural exchange. She states, "telecollaboration is characterized by institutionalized, electronically mediated intercultural communication under the guidance of a languacultural expert (i.e., teacher) for the purposes of foreign language learning and the development of intercultural competence" (BELZ, 2003).

Several academic institutions in Brazil and around the world have explored the context teletandem to promote telecollaborative partnerships between language learners. Researchers conducted within the Teletandem Brasil Project have highlighted the contribution of teletandem for the learners' linguistic and intercultural development (ANDREU-FUNO, 2015; MESSIAS; TELLES, mimeo; ZAKIR; ANDREU-FUNO; ELSTERMANN, 2015). Besides the positive impacts, researchers have also reported challenges such as the necessity of offering learners the opportunity to review and deconstruct stereotypes, bias and misunderstandings that occur in the sessions (ZAKIR, 2016; FRANCO, RAMPAZZO, 2016; SOUZA, 2016). 
Based on the challenges described above, we strongly believe that the mediation can enrich the process of learning foreign languages in linguistic and cultural terms in Teletandem. Considering the role and possible impacts of mediation on learners' development, in this article, we focus on teletandem mediation sessions through Facebook. For this purpose, we present an analysis of a mediator's actions towards the demands of a group of Brazilian students engaged in an institutional semi-integrated teletandem partnership in Portuguese and English. The theoretical foundation is composed by studies of the mediation and of the role of the mediator in teletandem (ZAKIR; ANDREUFUNO; ELSTERMANN, 2015; ARANHA; CAVALARI, 2014). Finally, we present the context, procedures, and results of an interpretivist qualitative research about mediation through Facebook.

\section{Mediation sessions}

The mediation session is an opportunity to maximize the experience of teletandem practice (ANDREU-FUNO, 2015; ELSTERMANN, 2016). Brammerts, Calvert and Kleppin (2001, p. 107) use the term counselling to refer to what in the Teletandem Brasil Project has been called mediation. The authors point that " $\mathrm{t}$ )he goal of every counselling session is to help learners to reflect on the decisions they have taken and/or to prepare new decisions for future action.". According to Guedes Evangelista \& Salomão (2019, p. 160), based on Salomão (2011a, p. 659), "[...] the mediator in teletandem is closely linked to the concept in Vygotsky's social theory of knowledge, which addresses the constitution and development of subjects through their social relations and language interaction".

Garcia (2015) acknowledge the mediation as one of the contexts in teletandem that works on what Vygotsky (1991) defines as Zone of Proximal Development (ZPD). This concept explains the distance between learners' real development, which relates to the learner's capacity of independent problem solving, and his/her potential level of development, determined by the solution of problems that the learner could accomplish with the help of a more capable individual. In this sense, learning in teletandem can happen by the collaboration between partners during the interaction sessions, and between learners and mediators.

The mediation session is also an important context for the teacher-mediator to focus on the intercultural dimension of the teletandem interactions. Such pedagogical aim demands both theoretical and practical knowledge regarding the organization and management of the partnerships on the part of teachers. Andreu-Funo (2015, p. 37) conceptualizes teletandem mediation sessions as: 
- | Teletandem mediation on Facebook

\begin{abstract}
[...] intriguing contexts in which there is a greater openness to the unusual and, thus, they are contexts for which (c) the planning of teaching and pedagogical activity is also displaced. After all, teachers do not prepare themselves for a conventional class in the same way as they do for a mediation session; there is no rigid pedagogical plan, but there is a policy of language learning under construction that guides the pedagogical action of the mediator.
\end{abstract}

As highlighted by the author, one of the main characteristics of the teletandem mediation is its openness to the unusual. This happens because its main focus is to provide pedagogical support based on learners' demands that emerge according to their experiences with their partners. Consequently, these necessities may range from linguistic issues to interpersonal and intercultural aspects of the partnerships.

It is important to mention that teletandem mediation sessions may vary on their format due the specificities of each institutional partnership (ANDREU-FUNO, 2015). Depending on characteristics such as time restriction, pedagogical demands, availability of mediator or level of integration to a language course curriculum, for example, mediation sessions can be conducted in different moments and formats. According to the necessities of each context, mediation can be conducted by the teachers synchronously or asynchronously, face to face or through different social media, e-mail or learning environments.

The semi-integrated institutional system of partnerships, which applies to the context focused on this article, for example, involves partner universities that conduct teletandem in different modalities: in an integrated modality, when the practice is integrated to the curriculum of the language course of one of the institutions, and in a nonintegrated modality, when the teletandem practice is not integrated to the curriculum of a language course of the partner institution (MESSIAS; TELLES, mimeo). The non-integrated teletandem may require volunteer students for teletandem practice. Therefore, they can do interactions as an extra and optional activity, apart from their classes, while in the partner university that conducts the integrated teletandem, students can do teletandem activities (sessions and mediation) as part of their curricular requirements to complete a language course.

As we can see, despite the differences in the mediation offer, it has been considered of extremely importance in institutional teletandem. In this regard, we emphasize the role played by the mediator in collaboration with the professor/mediator from the partner 
institution. The quality of the support offered to students also depend on the mediators dialogue to share their students experiences, compare their demands and negotiate changes during the process. Considering the importance of the mediators, in the section below we briefly describe their roles.

\section{The mediator}

The mediator in teletandem is usually a professor and/or researcher who is responsible for conducting the mediation sessions with the learners after interactions (ANDREU-FUNO, 2015). His/her importance is highlighted not only when s/he has to manage conflicts, but also as part of a teletandem partnership. The role of teletandem mediators has become more and more important as the project has been institutionalized and most of the interactions are held in groups of students (ZAKIR; ANDREU-FUNO; ELSTERMANN, 2015). We share Andreu-Funo's idea when she asserts that "[...] the mediator has the chance to perform the role of the observer along the interactions and, from his/her observations, he/she may provide relevant issues to maximize the participants' learning process" $(2015$, p. 40).

We emphasize that autonomy is not taken away from the learners. They are rather challenged towards it. The mediator provides an open and reflective conversation in order to make the learners reflect (SCHÖN, 1983) and evaluate their teletandem experience (MEZIROW, 1991, 2000).

Some recent teletandem researches focused on the synchronous mediation sessions (ANDREU-FUNO, 2015; GARCIA, 2015; ELSTERMANN, 2016) and emphasized the necessity of mediation in institutional teletandem contexts. However, we consider that the role of the mediator is also crucial in an asynchronous contexts such as a Facebook private group. This is the context from where we collected our data for the study described in this article. In the next section, we present our methodological procedures.

\section{Methodology}

Our study was conducted within the context of a semi-integrated teletandem institutional partnership (MESSIAS; TELLES, mimeo) that was carried out by a public Brazilian university and a private North-American university. The mediation sessions for the students from the Brazilian university, object of analysis in this study, were conducted through a closed Facebook group. The mediator, a Brazilian professor of English, was responsible for creating and adding the teletandem participants to the group. 
The Facebook group was chosen because the teletandem interactions were nonintegrated and happened during lunchtime for the students in the Brazilian institution and they could not stay after the session for a face-to-face mediation, since they needed to head to the university restaurant, which worked on a strict service timetable. This restriction is also due to the fact that, in this study, most teletandem partnerships carried by the Brazilian university have been conducted as a non-integrated program (MESSIAS; TELLES, mimeo), so, in this modality, the participants and mediators are required to be more flexible to adjust to the characteristics of each partnership. Therefore, depending on the country and the classes, the interactions can take place at lunchtime in Brazil. Many interactions that happen around that time do not allow us to conduct the face-to-face mediation sessions afterwards. Based on that, our decision was to use Facebook in order to keep in touch with our participants and try to share their session experience, and make them reflect about it.

The data collected for the present analysis was generated during the second semester of 2015. The focus of the analysis is the mediation process carried out by the Brazilian mediators and teletandem participants in a Facebook group. Mediators' and teletandem participants' messages on Facebookwere shared in Portuguese asynchronously. For the purpose of sharing them in this article, we chose to translate them.

Frequency of participation of the mediators and students/participants were measured in terms of number of postings on Facebook, which is summarized on Table 1, below.

Table 1. Frequency of participation of mediators and teletandem participants on Facebook

\begin{tabular}{|c|c|c|c|c|c|c|c|}
\hline $\begin{array}{c}\text { Mediator } \\
(\mathrm{M})\end{array}$ & $\begin{array}{c}\mathrm{N}^{0} \text { of } \\
\text { posts }\end{array}$ & Participants $(\mathrm{P})$ & $\begin{array}{c}\mathrm{N}^{0} \text { of } \\
\text { posts }\end{array}$ & Participants $(\mathrm{P})$ & $\begin{array}{c}\mathrm{N}^{0} \text { of } \\
\text { posts }\end{array}$ & Participants (P) & $\begin{array}{c}\mathrm{N}^{0} \text { of } \\
\text { posts }\end{array}$ \\
\hline Daiane & 69 & Michel & 03 & Vivian & 09 & Adriana & 07 \\
\cline { 3 - 8 } & & Carla & 09 & Fernando & 06 & Tatiana & 01 \\
\hline Kátia $^{3}$ & 06 & Helen & 06 & Aline & 04 & Laura & 03 \\
\cline { 3 - 8 } & & Julia & 06 & Jenifer & 05 & João & 01 \\
\hline TOTAL: & 75 & Leda & 06 & Lucas & 06 & TOTAL: & 72 \\
\hline
\end{tabular}

3 Kátia was Daiane's advisee and participated in the Facebook group as her assistant in mediating students' messages. 
The names of mediators and participants presented on Table 1 are fictitious in order to guarantee their anonymity. Participants of this research signed a consent form allowing the analysis of their data. Daiane's and Kátia's messages posted on Facebook were directed to all participants or were responses to their individual questions or contributions to the suggested debates. As it can be seen on the table, Daiane, one of the authors of this article, was the most active mediator in the group with a total of 69 messages, so the analysis of the data is focused on her role in the interaction with the students on Facebook.

The process of organizing the data consisted of the following steps: (a) reading the Facebook private group posts; (b) separating the general messages (organizational messages, such as general posting requests, management of absences and time changes); (c) separating the mediator's and teletandem participants' messages about each interaction session, and (d) identifying the main themes of each post. The messages were organized on a Google sheet and shared with the authors. Its initial organization revealed the emergence of the following data (a) the most important characteristics of the mediation, (b) the role played by the mediators on the context of Facebook, (c) and the issues that teletandem participants shared. For the purpose of the qualitative analysis of this study, the main themes were summarized and presented on Table 2. Since the focus of this study is on the role of the mediator, the topics identified on Daiane's posts are highlighted in bold on the table below. They will be discussed in the next sections. 
- | Teletandem mediation on Facebook

Table 2. List of general and subtopics of Facebook posts

\begin{tabular}{|c|c|c|}
\hline Author & General topics & Subtopics \\
\hline \multirow{3}{*}{ Mediator (Daiane) } & Encouragement & $\begin{array}{l}\text { - Welcoming; } \\
\text { - Compliment; } \\
\text { - Motivation. }\end{array}$ \\
\hline & Teletandem theory & $\begin{array}{l}\text { - Autonomy, reciprocity, separated use of languages and } \\
\text { collaboration; } \\
\text { - Setting and sharing clear goals; } \\
\text { - Negotiating correction; } \\
\text { - Focusing on form and content; } \\
\text { - Learning strategies; } \\
\text { - Drawing attention to (trans)cultural issues and to } \\
\text { comparisons. }\end{array}$ \\
\hline & Organizational issues & $\begin{array}{c}\text { - Post requests; } \\
\text { - Time changes due to different time zones; } \\
\text { - Management of absences; } \\
\text { - Acknowledgement of replacement for missed sessions } \\
\text { between partners. }\end{array}$ \\
\hline Participants & $\begin{array}{l}\text { Descriptions } \\
\text { Reflection } \\
\text { Assessment }\end{array}$ & $\begin{array}{c}\text { - Partner; } \\
\text { - Session; } \\
\text { - Difficulties; } \\
\text { - Expectations } \\
\text { - Approached topics. } \\
\text { - Interpersonal relations; } \\
\text { - Strategies; } \\
\text { - Learning process; } \\
\text { - Adjustments; } \\
\text { - Emotions; } \\
\text { - Cultural differences. }\end{array}$ \\
\hline
\end{tabular}

The analysis of the Facebook posts is oriented by the themes that were initially identified. By considering the participants' demands, the main foci of our qualitative analysis were: to map (a) the characteristics of this mediation context, (b) the role of the 
mediator, and (c) how the mediation was conducted. The excerpts analyzed in this article were originally posted in Portuguese on the Facebook private group and translated into English.

\section{Analysis: the role of the mediator}

This section is divided into three subsections that refer to the main characteristics identified on the mediator's posts: organizational procedures, messages of encouragement and guidelines, and review of teletandem theories.

\subsection{Organizational procedures}

As it was mentioned in section 4, Daiane was the mediator of the institutional partnership analyzed in this article. Her mediation process consisted, to a great extent, of providing learners with encouraging messages and in providing explicit orientation (characterized by the use of the imperative mode as shown on the collected data). Organizational issues were also managed by both the mediator and the assistant mediator, Katia. For the purpose of this section, the focus will be on the role of Daiane in the process of encouragement and in providing orientation based on the teletandem theory and principles.

As O'Dowd (2013) describes, telecollaborative teachers have organizational, pedagogical and digital competences. It is possible to identify such characteristics as well as the attitudes of the telecollaborative teachers in the context analyzed in this article. The organizational competences described in O'Dowd's article (2013) refer to the abilities of the telecollaborative teacher to contact partners and establish criteria for online exchanges in an institutional level (ARANHA; CAVALARI, 2014). In the current phase of teletandem project, there is a network of researchers who establish partnerships among the universities that are involved in the project. Thus, this previous contact between the Brazilian and the American university had already been made by Daiane, the mediator of our research study.

Although it is possible to identify organizational procedures in our data, we consider that they are part of what $\mathrm{O}^{\prime}$ Dowd (2013) includes in the pedagogical competences of the telecollaborative teacher, since $s / h e$ 
- | Teletandem mediation on Facebook

[...] can integrate appropriate assessment procedures and rubrics which accurately reflect the activities which students carried out during their exchange [and] can explain clearly to students what is expected from them during an exchange - deadlines, performance objectives, learning outcomes etc. (O'DOWD, 2013, p. 10).

Considering this, the first characteristic that our data have evidenced was the organizational procedures and reinforcement messages. These indicate the guidelines that the mediator adopts during the mediation process to guide students towards accomplishing the agreements of using the Facebook group to share their experiences. As we can see on excerpt 1 below, the mediator describes the criteria for the postings (in Portuguese or in English) and their purposes (sharing experiences).

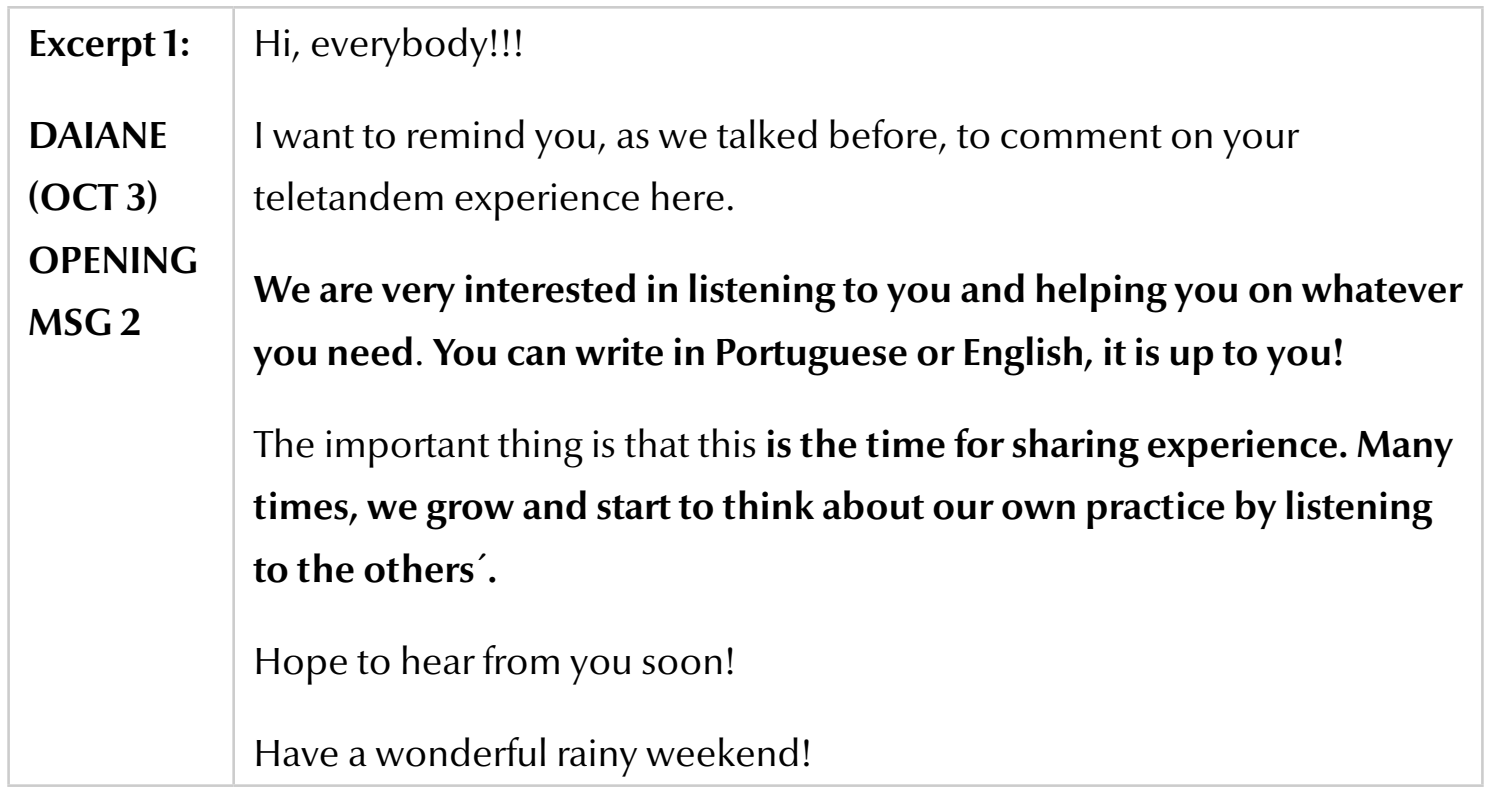

Excerpt 1 fulfills what we have just mentioned above from O'Dowd (2013), regarding one of the roles of the telecollaborative teacher in managing partnerships and establishing criteria for the learning process, both in an inter-institutional and in a pedagogical level. Daiane includes and integrates procedures and provide clear explanations on what the students are expected to do when posting on Facebook. Considering an alignment to the theoretical foundation of mediation in teletandem, she presents a flexible rule, seen in "You can write in Portuguese or English", to encourage learners to share their experiences.

Daiane's organizational messages, as we can see on the following excerpt, also aimed at reminding students of the changes during the partnerships (cancellations, time changes) and at warning them of the importance of not missing the sessions. Laura and 
Natália are mentioned because they had missed an interaction and it was not well seen by the mediator. In order to solve the emergency, two extra students were called to replace them and as they enjoyed the experience, they asked permission to be part of the group. This is only possible if Laura and Natália give up. So that is why the mediator brings this topic to Facebook.

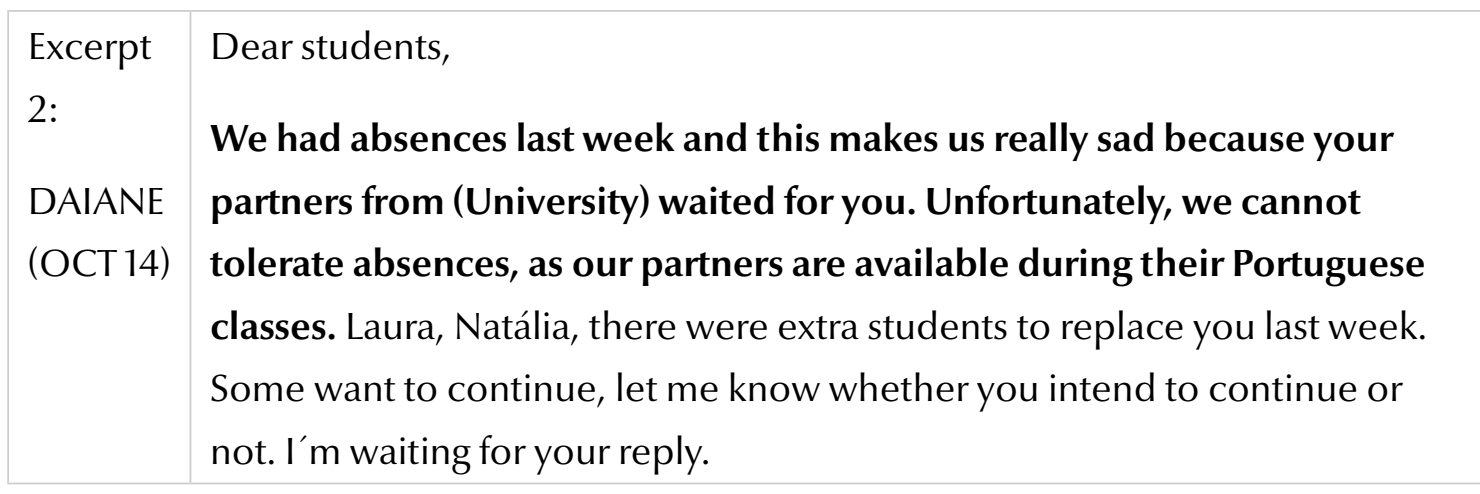

The organization procedures summarized in this section reveal the mediator's active attention to the whole partnership process. It also shows the necessity of guaranteeing that the students keep their partnerships until the end of the interactions period. It is important to highlight the personal approach used by Daiane to call students' attention to the impact and consequences of their absences (partners waiting in their Portuguese classes, finding substitute partners and cancellation of the absent students' participation). Managing student participation in the teletandem sessions was also a great part of the organizational task of the mediator. This was particularly true when we consider the volunteer participation of the Brazilian students and the context of non-integrated teletandem partnerships in the Brazilian university that we focused on this study. In this case, Daiane may have appealed to the frustration that student absences caused to their partners abroad ("We had absences last week and this makes us really sad because your partners from (University) waited for you"). She attempted to develop students' awareness of the collaboration that is inherent to the Teletandem context.

In this subsection, we described the main organizational issues and how they were presented by the mediator. In the following section, we analyze Daiane's encouragement messages provided during the mediation process. 
- | Teletandem mediation on Facebook

\subsection{Encouragement messages}

Among the characteristics found in Daiane's posts, maybe the encouragement messages have played the most important role in terms of recurrence. Even when the topics of the posts were related to different issues, the mediator would always motivate students to keep their participation and face the possible difficulties reported during the teletandem interaction. In the excerpts below, Daiane's encouragement messages are underlined and in bold.

\begin{tabular}{|c|c|}
\hline Excerpt 3: & $\begin{array}{l}\text { Keep in mind that you should help each other under the learning goals } \\
\text { you have! Negotiate, adjust and take advantage of the context and the } \\
\text { partnership. Nervousness and shyness are common } \underline{\text { but, from now on, }} \\
\text { you will become more confident for the interaction. Keep going and } \\
\text { count on me. (Wink emoticon) }\end{array}$ \\
\hline $\begin{array}{l}\text { Excerpt 4: } \\
\text { DAIANE }\end{array}$ & $\begin{array}{l}\text { That's great, Vivian!!! I must tell you that I was worried about your } \\
\text { nervousness last week. You will see, from now on, things will flow. Keep } \\
\text { going. (Wink emoticon). }\end{array}$ \\
\hline Excerpt 5: & $\begin{array}{l}\text { Good job, Jéssica!!! I think she will get used to the Portuguese language } \\
\text { too, as she listens to you. Let's hope!!! You will be more familiar in the } \\
\text { course of time. Go for it!! (Wink emoticon) }\end{array}$ \\
\hline Excerpt 6: & $\begin{array}{l}\text { Hi, Letícia, yes, keeping the same partner tends to be more comfortable } \\
\text { and productive, don't you think? I hope you keep the same partner from } \\
\text { now on. I am glad things worked out well in spite of the inconvenient. Go } \\
\text { for it!! }\end{array}$ \\
\hline $\begin{array}{l}\text { Excerpt 7: } \\
\text { DAIANE }\end{array}$ & $\begin{array}{l}\text { Always provide feedback! This motivates and pushes you on, don't you } \\
\text { think? What about the English language? Can you notice the same things? } \\
\text { Very good!! Congratulations and go for it!! (Wink emoticon). }\end{array}$ \\
\hline $\begin{array}{l}\text { Excerpt 8: } \\
\text { DAIANE }\end{array}$ & $\begin{array}{l}\mathrm{Hi} \text {, Ana Paula! We don't like absences, do we? } \underline{\text { But }} \underline{\text { I am glad you talked to }} \\
\text { another partner and that it was interesting. Keep going! }\end{array}$ \\
\hline $\begin{array}{l}\text { Excerpt 9: } \\
\text { DAIANE }\end{array}$ & $\begin{array}{l}\text { That's great, Juliana!!! Time brings benefits to the partnerships, don't you } \\
\text { think? I am glad you are enjoying the experience, learning, helping each } \\
\text { other, making friends and having fun. Great!!!! Good luck! }\end{array}$ \\
\hline
\end{tabular}


As we can notice, it is possible to identify a pattern in the mediator's messages, since there is a recurrence of the term "Go for it!!!". Such recurrence is possibly related not only to Daiane's positive profile, but also to the context in which the mediation was held. Whereas in a face-to-face mediation session, the whole group is involved in the discussions that emerge after the teletandem sessions, in a Facebook private group, we could observe that the interactions are more frequent between a student and the mediator. Thus, the encouragement messages can be understood as an effective way for the mediator to keep in touch with students and to motivate them to solve some of the difficulties reported in the subsequent teletandem interactions. Daiane's efforts are clearly seen and also her will for a comfortable and pleasant telecollaborative experience in language learning.

Another characteristic that can be evidenced in Daiane's posts is her focus on the students' development and on the good aspects of the teletandem interaction that they report. The use of the adversative conjunction "but" in excerpts 3 and 8 and the concessive conjunction "in spite of" in excerpt 6 provides evidence that Daiane considers the difficulties but acknowledges the success of each interaction. As an experienced teletandem researcher and mediator, Daiane knows that the first interactions may cause student nervousness and anxiety (ROCHA; LIMA, 2009). However, as the contact between the partners becomes more frequent, these feelings tend to fade. Excerpts 4, 5 and 6 provide examples of that when Daiane uses the adverbs "from now on" and "in the course of time" to highlight the fact that the next interactions will certainly be more successful. This can also be evidenced in excerpt 9, when Daiane says that time can bring benefits to the partnerships. This is what we have seen throughout the years, partners tend to establish a comfort zone and lower their level of anxiety as time passes by and they develop familiarity. The partnership tends to go beyond the learning exchanges by overcoming anxiety towards friendships.

The excerpts analyzed in this section provide examples of the mediator's role in encouraging students' improvement and development during their teletandem interactions. Through direct contact with each student, Daiane reinforces what she has been working on and she tries to counteract the difficulties that are typical of first contacts between telecollaborative partners.

In the next section, we focus on how the mediator provides guidelines to students and revisits teletandem theories through the Facebook mediation section. 
- | Teletandem mediation on Facebook

\subsection{Providing guidelines and revisiting teletandem theories}

The principles of autonomy, reciprocity and separated use of languages (VASSALLO; TELLES, 2006), which have grounded teletandem interactions, are based on tandem principles, as described by Schwienhorst (1998) and Brammerts (2002). Mediation sessions via Facebook have shown themselves to be an effective context either to introduce or to revisit these principles through the mediator's posts. In the excerpts below, the reference to teletandem theoretical principles and characteristics are underlined and highlighted in bold.

\begin{tabular}{|c|c|}
\hline Excerpt 10: & $\begin{array}{l}\text { Let your goals evident to your partner so that she will be able to help you } \\
\text { and the gains will be clearer. Remember the reciprocity, autonomy and } \\
\text { separated use of languages teletandem principles. Best wishes!! (Wink } \\
\text { emoticon). }\end{array}$ \\
\hline Excerpt 11: & $\begin{array}{l}\text { Remember the principle of reciprocity and think about how you } \\
\text { can help your partner to take greater advantage of the experience. } \\
\text { Always negotiate, seek adjustments and enjoy the most. I wish you very } \\
\text { productive interactions! Count on me to whatever you need! (Wink } \\
\text { emoticon). }\end{array}$ \\
\hline Excerpt 12: & $\begin{array}{l}\text { Be attentive for the Spanish language and establish, with her, the } \\
\text { correction criteria you will follow. It is important that both of you tell } \\
\text { each other how you would want/like to be corrected. Then you will } \\
\text { avoid problems. Remember that you must help each other and this has } \\
\text { to be reciprocal. I wish you an amazing experience. (Wink emoticon). }\end{array}$ \\
\hline $\begin{array}{l}\text { Excerpt 13: } \\
\text { DAIANE }\end{array}$ & $\begin{array}{l}\mathrm{Hi} \text {, Juliana!! The themes you went through are very interesting! I } \\
\text { emphasize what you said: "we help each other"! This is the key for } \\
\text { any partnership, both of you need to be aware of helping each other } \\
\text { towards learning. Very nice!! (Wink emoticon). }\end{array}$ \\
\hline
\end{tabular}




\section{Excerpt 14: Yes, I think it is important that you negotiate, between yourselves, what you consider more productive. I agree that the interaction DAIANE should not become "a boring class" but I also think that pronunciation/ particularities of languages can reinforce the learning goals you have for the partnership. It is good to remember that teletandem has the learning differential besides a talk to a foreigner. Paying attention to what the partner says and how he does it is essential to provide him feedback afterwards. Have this in mind! Big hug. \\ Excerpt 15: See how interesting it is: he takes notes, is attentive and has efforts to communicate. Those things show that teletandem is not a mere chat \\ DAIANE but a context for learning! Good luck!! \\ Excerpt 15: Remember that the partnership is about helping each other in learning. DAIANE Negotiate with your partner, discuss the correction criteria and ways of correcting. In teletandem, we develop the ability to listen to what the partner says (but also to HOW he says something). Good luck!!}

One of the most recurrent characteristic in Daiane's approach to provide guidelines is the use of imperative mode. She also gives several general statements defining what teletandem practice is or is not by referring to the teletandem main theoretical concepts. This form of approach can be observed in excerpts 10, 11, 12, in phrases such as "Make your goals evident", "Remember the principle of reciprocity and think how [...], always negotiate, seek adjustments [...]", "Be attentive [...] Remember that you must help each other and this has to be reciprocal."

Explicit orientations are present, to a great extent, in Daiane's replies to the learners' posts. Due to the space restriction and to our purpose of analysis, there is no space in this article to analyze these posts. Nevertheless, we can observe that this pattern (use of imperative mode and general and conclusive statements about teletandem) and the focus on the basic teletandem principles (reciprocity, autonomy, separated use of languages) tended to be present in Daiane's replies. Regardless of the content of the participants' messages, she always replied to their demands and also added recommendations. This recurrence may result from the limitations of the context to approach more specific issues in depth and from the previous experience in which learners would not follow the principles and have the results far from expected. 
Therefore, Daiane keeps motivating and providing students with instructions, warnings and inspirational words. These basic teletandem principles promote collaboration and learning. Moreover, the emphasis on the main teletandem principles, mainly presented in the imperative mode, may indicate the need to distinguish the teletandem context from other practice and learning contexts as she mentions on excerpt 15: 'teletandem is not a mere chat but a context for learning'. This understanding is crucial to learners when having teletandem interactions.

Daiane's posts also demonstrate her concern to remind students of how different teletandem interactions are from casual/daily conversations (excerpt 12, 14, 15). According to Telles (2009), this difference is marked by the fact that learners are supposed to listen to the partner and develop the ability to pay attention to what they are saying as well as how things are being said. Since the goal of the interactions is helping a partner to learn a language, negotiation of strategies, discussion of topics and different ways of correction are central in the teletandem context.

In the following section, we present some final considerations regarding the Teletandem mediation sessions on Facebook.

\section{Final remarks}

In this work, we approached the mediation conducted in a private Facebook group. Considering the characteristics of this social media and the limitations of the mediation for the analyzed group, this study raises questions about the role of the mediator and the implications of teletandem mediation on Facebook.

Relevant issues from the Teletandem interactions could be revisited in the mediation sessions and then work as a trigger brought to the group. The person who plays the mediator role should be sensible to explore the mediation moment in order to develop the intercultural competence and more reflexive and autonomous actions.

The mediation sessions in the teletandem context demand a great participation of the mediators/ teachers. They should be a moment to explore and reinforce the subjects and situations lived and brought to learners in interactions. From the time the mediator creates a positive atmosphere, the learners start to realize that sharing contributes to her/ his own benefits and to the other's. Feedback from the interactions and the experience is of great importance and can work as a guideline to move back and forth, demanding more specific actions. 
We recognize the potential of face-to-face meeting to the participants for the mediation sessions. The visual and extra-visual communication are of great support as well as the promoted interaction among the participants and mediator. However, considering our constraints, the Facebook mediation made itself new and stressed its importance in this experience. The presented findings suggest that Facebook was a suitable alternative for the mediation. Given the fact that this social network is of easy access and used by most of the Brazilian learners who participated in this study, the interaction and visualization of the shared messages were facilitated in this context. Besides that, the participants could share their experiences during the best time for them, which has solved the problem of not having face-to-face mediation sessions due to lunchtime in Brazil.

On the other hand, the asynchronous nature of Facebook posts may have had some impact on the role of the mediator. According to the presented analysis, we can highlight her efforts to keep learners' motivation and participation in the group, either commenting on their messages or drawing their attention to the importance of posting in the group. Nevertheless, such a characteristic might have led the posts to be more related to foster motivation than to promote collective reflection through interaction (ANDREUFUNO, 2015).

Analyzing the posts in our data, we identified that the most recurrent type of message is the one in which the mediator encourages learners' participation both in teletandem sessions and on the Facebook mediation private group. The mediator seems to be aware of her limited access to solve or to "guide" immediately all the participants' issues and revolves to teletandem principles to encourage them to continue discussing the topics they mention on the posts. This has proven to be possible to address immediately in face-to-face mediation sessions.

In regards to the learners' contributions to the group, when reading the messages and reports from each other, reflection processes on their own learning were expected to be developed. The participants were offered support to get back to their own comments as a form of growing, evaluating and following-up their experiences. It is possible to notice progress in the reports when the participants describe their interaction sessions and that offers information for the mediator to evaluate the group, their actions and needs and provide support/help.

The mediation session via Facebook shows the presence of the mediator, although the expectations of promoting deep reflection are not completely fulfilled, maybe, among other reasons, due to the fact that emphasis was given on keeping students' motivation. This does not mean, however, that this type of context for mediation sessions is not 
- | Teletandem mediation on Facebook

important nor help the learners. It is part of the Teletandem institutionalized partnerships as long as it foresees both the teletandem interactions and the mediation sessions.

The present study has some limitations that should be noted. The most important one is the restriction of the analysis to the mediator's messages. Considering the large amount of data generated in the exchanged messages on Facebook, for the purpose of this study we focused on the role of the mediator. Since our scope of analysis was previously delimited, further studies could approach the interaction between the mediator and the teletandem participants. It would be also fruitful to pursue further research about the differences between face-to-face mediation and mediation in online contexts. This kind of research would contribute to the development of mediation practices and approaches.

\section{References}

ANDREU-FUNO, L. B. A. Teletandem: um estudo sobre identidades culturais e sessões de mediação da aprendizagem. 2015. Dissertation (Ph.D. in Applied Linguistics) - Instituto de Biociências, Letras e Ciências Exatas, Universidade Estadual Paulista, São José do Rio Preto, 2015.

ARANHA, S.; CAVALARI, S. M. S. A Trajetória do Projeto Teletandem Brasil: da modalidade Institucional não-integrada à Institucional Integrada. The Especialist (PUCSP), v. 35, p. 7088, 2014.

BELZ, J. A. From The Special Issue Editor. Language Learning \& Technology, v. 7, n. 2, p. 2-5, 2003. Available at: http://Llt.Msu.Edu/Vol7num2/Speced.Html. Access: May 25 2011.

BRAMMERTS, H. Autonomous Language Learning In Tandem. In: LEWIS, T.; WALKER, L. (eds.). Autonomous Language Learning In-Tandem. Sheffield, Uk: Academy Electronic Publications, 2002. p. 27-36.

BRAMMERTS, H.; CALVERT, M.; KLEPPIN, K. Ziele und Wege bei der individuellen Lernberatung. In: BRAMMERTS, H.; KLEPPIN, K. (eds.). Selbstgesteuertes Sprachenlernen im Tandem. Tübingen: Stauffenburg, 2001. p. 53-60.

DOUGHTY, C.; WILLIAMS, J. Focus on Form in Classroom. Second Language Acquisition. Cambridge: Cambridge University Press, 2004. 
ELSTERMANN, A. K. Learner Support in Telecollaboration: Peer Group Mediation in Teletandem. 2016. Dissertation (PhD in Applied Linguistics) - Fakultät für Philologie, RuhrUniversität Bochum, Bochum, 2016.

FRANCO, G. R.; RAMPAZZO, L. Estereótipos como sedimentadores de ideias de hegemonia em parcerias de teletandem institucional semi-integrado. Domínios de Lingu@gem, v. 10, n. 4, p. 1302-1325, 2016.

GARCIA, D. N. M. A logística das sessões de interação e mediação no teletandem com vistas ao ensino/aprendizagem de línguas estrangeiras. Revista Estudos Linguísticos, v. 44, n. 2, p. 725-738, 2015.

GUEDES EVANGELISTA, M.; SALOMÃO, A. Mediation in Teletandem: from face-to-face sessions to reflective journals. Pandaemonium, São Paulo, v. 22, n. 36, p. 153-177, jan.-abr. 2019.

LONG, M. H. Focus on form: A design feature in language teaching methodology. European-North-American Symposium on Needed Research in Foreign Language Education. Bellagio, Italy: Rockfeller Centre, 1988.

MESSIAS, R. A. L.; TELLES, J. A. Teletandem como "terceiro espaço" no desenvolvimento de professores de línguas estrangeiras. (mimeo)

MEZIROW, J. Learning as Transformation. Critical Perspectives on a Theory in Progress. San Francisco: Jossey-Bass, 2000.

MEZIROW, J. Transformative Dimensions of Adult Learning. San Francisco, California: Jossey-Bass, 1991.

O'DOWD, R. The competences of the telecollaborative teacher. The Language Learning Journal, v. 43, p. 194-207, 2013. Available at: http://dx.doi.org/10.1080/09571736.2013.85 3374. Access: Jan. 182016.

O'DOWD, R. Supporting In-Service Language Educators in Learning to Telecollaborate. Language Learning \& Technology, v. 19, n. 1, p. 63-82, 2015. 
- | Teletandem mediation on Facebook

ROCHA, C. F.; LIMA, T. C. S. Questionamentos sobre a presença do mediador na prática de interação em teletandem. In: TELLES, J. A. (org.). Teletandem: um contexto virtual, autônomo e colaborativo para aprendizagem de línguas estrangeiras no século XXI. Campinas: Pontes Editores, 2009. p. 229-239.

SCHENKER, T. Intercultural Competence and Cultural Learning through Telecollaboration. CALICO Journal, v. 29, n. 3, p. 449-470, 2012.

SCHÖN, D. A. The reflective practitioner. San Francisco: Basic Books, 1983.

SCHWIENHORST, K. Matching pedagogy and technology - Tandem learning and learner autonomy in online virtual language environments. Language Teaching On-Line, 1998.

SOUZA, M. G. Teletandem e mal-entendidos na comunicação intercultural online em língua estrangeira. 2016. Dissertation (PhD in Applied Linguistics) - Instituto de Biociências, Letras e Ciências Exatas, Universidade Estadual Paulista, São José do Rio Preto, 2016.

TELLES, J. A. Projeto Teletandem Brasil: Línguas Estrangeiras para Todos - Ensinando e Aprendendo línguas estrangeiras in-tandem via MSN Messenger. Faculdade de Ciências e Letras de Assis, UNESP, 2006. Available at: http://www.teletandembrasil.org/site/docs/ TELETANDEM_BRASIL_completo.pdf. Access: July 022014.

TELLES, J. A.; VASSALLO, M. L. Teletandem: uma proposta alternativa no ensino/ aprendizagem assistidos por computadores. In: TELLES, J. A. (org.). Teletandem: um contexto virtual, autônomo e colaborativo para aprendizagem de línguas estrangeiras no século XXI. Campinas: Pontes Editores, 2009. p. 43-61.

VASSALLO, M. L.; TELLES, J. A. Ensino e aprendizagem de línguas em tandem: princípios teóricos e perspectivas de pesquisa. In: TELLES, J. A. (org.) Teletandem: um contexto virtual, autônomo e colaborativo para aprendizagem de línguas estrangeiras no século XXI. Campinas: Pontes Editores/FAPESP, 2009. p. 21-42.

VASSALLO, M. L.; TELLES, J. A. Foreign language learning in-tandem: Theoretical principles and research perspectives. The ESPecialist, São Paulo: Educ, v. 27, n. 1, p. 83-118, 2006.

VYGOTSKY, L. S. A formação social da mente: o desenvolvimento dos processos psicológicos superiores. 4. ed. São Paulo: Martins Fontes, 1991. 
WELSCH, W. Transculturality: the puzzling form of cultures today. Spaces of Culture: City, Nation, World. In: FEATHERSTONE, M.; LASH, S. London: Sage, 1999. p. 194-213.

ZAKIR, M. A.; ANDREU-FUNO, L. B. A.; ELSTERMANN, A. K. La pratica riflessiva nei contesti di telecollaborazione. In: LEONE, P. et al. (org.). Osservazione di classe, insegnamento linguístico e (tele)collaborazione. Florence, Italy: Franco Cesati, 2015. p. 104-113.

ZAKIR, M. A. Cultura e discurso: uma análise translinguística de interações de teletandem. Letras de Hoje, v. 51, n. 1, p. 147-156, jan./mar. 2016.

COMO CITAR ESTE ARTIGO: GARCIA, Daniela Nogueira de Moraes; SOUZA, Micheli Gomes de. Teletandem mediation on Facebook. Revista do GEL, v. 15, n. 3, p. 155-175, 2018. Disponível em: https://revistadogel.gel.org.br/

DOI: http://dx.doi.org/10.21165/gel.v15i3.2400

Submetido em: 12/11/2018 | Aceito em: 17/12/2018. 